\title{
THE MEASUREMENT OF GAS EMISSIONS STATUS DURING THE COMBUSTION OF WOOD CHIPS
}

\section{MERENJE EMISIJE GASOVA TOKOM SAGOREVANJA ČIPSA OD DRVETA}

\author{
Angelovič M, Findura P, Jobbágy J, Fiantoková Soňa, Križan M \\ Slovenská pol'nohospodárska univerzita v Nitre, Technická fakulta, \\ Katedra strojov a výrobných systémov, Tr. A. Hlinku 2, Nitra, 949 76, \\ e-mail: marek.angelovic@uniag.sk
}

\begin{abstract}
The aim of this paper was a monitoring of harvest process of wood material. Measurement of energy potential during burning process was realized with wood chips. Wood chips contained $20 \%$ of moisture. During this experiment we detected an influence of wood chips moisture content on $\mathrm{CO}, \mathrm{CO}_{2}, \mathrm{NO}$ production and $\mathrm{NO}_{2}$ emission gases production. All measured emissions values were within the normative range defined by Decree 356/2010 Coll of the Ministry of Agriculture, Environment and Regional Development of the Slovak Republic.

Key words: wood chips, renewable energy resources, $\mathrm{CO}, \mathrm{CO}_{2}, \mathrm{NO}, \mathrm{NO}_{2}$ emissions, emission limits, burning process.

\section{INTRODUCTION}

Chips are 2-4 $\mathrm{cm}$ long pieces of wood, which are produced by wood waste chipping e.g. thin scrap of thinning stands or branches. Chips are the waste product of the timber industry and their energy utilization is regular in many countries. In Denmark, as well as in Austria there are many larger local boiler houses, which burn wood chips. The advantage of wood chips is faster drying and they enable an automatic operation of the energy boilers when using the stack and the fuel conveyor (Biomasa, 2014).

Information about the efficiency of the capturing, conversion and storage of solar energy in the form of biomass is neccessary for the evaluation of available potential of this energy source. Net primary production is an importatnt information, when considering biomass harvest for the assessment of the plant suitability, which represents the amount of carbon from atmospheric carbon dioxide captured through the process of photosynthesis and converted to biomass by plant. By means of biomass oxidation, i.e. oxidation of organic compounds originated in the process of photosynthesis, it is possible to release and utilize the accumulated solar energy again (Gaduš, 2006).

Characteristics of biomass are importatnt, when considering combustion, where the main indicators of quality are values, as the content of water in the biofuel, chemical composition of combustible fuel, content of volatile matter and calorific value of the biofuel (Maga, Piszczalka, 2006).
\end{abstract}


Usable biomass comes from a wide variety of plants and contains a wide range of chemical substances, however its energy content is mostly similar. The calorific value of

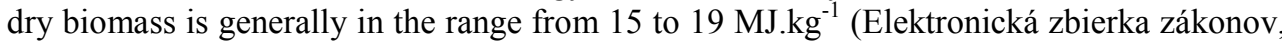
2010).

The heat from the biomass can be obtained by direct combustion of biomaterials or indirectly, e.g. while cooling engines, which burn biofuel, or by electrical energy production.

Direct way of heat production is defined by burning of plant or wood biomass. Higher thermal efficiency of new energy devices requires less biofuel to ensure the same amount of energy (Piszczalka, Jobbágy, 2011).

Table 1. The calorific value of different types of biomass (Moderná mechanizácia

\begin{tabular}{|c|c|c|c|c|c|}
\hline \multirow[b]{3}{*}{ Type of fuel } & \multirow{3}{*}{$\begin{array}{c}\text { Water content } \\
\%\end{array}$} & pol'nohospodá & rstve, 2013) & & \\
\hline & & \multirow[b]{2}{*}{$\begin{array}{c}\text { Calorific } \\
\text { value } \text { MJ.kg }^{-1}\end{array}$} & \multicolumn{3}{|c|}{\begin{tabular}{|r|} 
Volumetric weight \\
\end{tabular}} \\
\hline & & & $\mathrm{kg} \cdot \mathrm{m}^{-3}=\mathrm{kg}_{1} \cdot \mathrm{plm}$ & kg.prm ${ }^{-1}$ & kg.prms ${ }^{-1}$ \\
\hline deciduous wood & 15 & 14,605 & 678 & 475 & 278 \\
\hline coniferous wood & 15 & 15,584 & 486 & 340 & 199 \\
\hline pine & 20 & 18,40 & 517 & 362 & 212 \\
\hline willow & 20 & 16,90 & & & \\
\hline alder & 20 & 16,70 & & & \\
\hline hornbeam & 20 & 16,70 & & & \\
\hline acacia & 20 & 16,30 & & & \\
\hline oak & 20 & 15,90 & 685 & 480 & 281 \\
\hline fir & 20 & 15,90 & & & \\
\hline ash & 20 & 15,70 & & & \\
\hline beech & 20 & 15,50 & 670 & 469 & 275 \\
\hline spruce & 20 & 15,30 & 455 & 319 & 187 \\
\hline birch & 20 & 15,00 & & & \\
\hline poplar & 20 & 12,90 & & & \\
\hline wood chips & 30 & 12,18 & & & 210 \\
\hline
\end{tabular}

\section{MATERIAL AND METHODS}

The aim of our study was to monitor the opportunity of wood pulp harvesting and its subsequent utilization for energy purposes by combustion of wood chips (Figure 1).

Biological material (wood chips) was cultivated and subsequently processed on the premises of agricultural company in Rastislavice, Nové Zámky.

The processing of wood pulp was realized by JUNKKARI HJ 260 GT mobile chipper (Figure 2). Wood chips were transported from the outside area and stored in incineration plant.

Combustion of wood chips was realized in incineration plant of Menert-Therm company in Šala, which provides heating for some residential buildings, customized for the incineration of rape straw and wood chips packages. Wood chips with a moisture content of $20 \%$ were used as combustion material (Figures 3,4). 


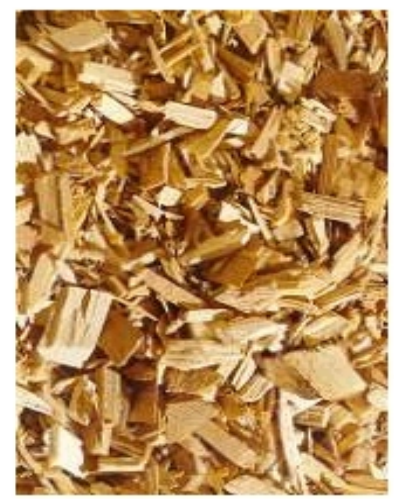

Fig 1. Wood chips

S1. 1. Čips od drveta

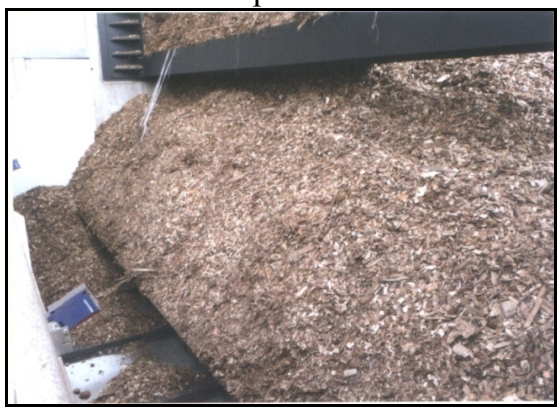

Fig 3. Stack of wood chips

Sl. 3. Zalihe čipsa od drveta

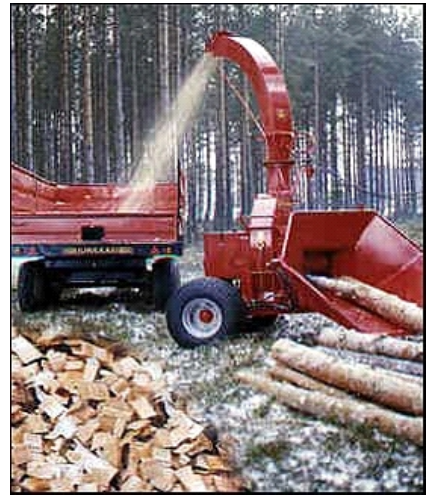

Fig 2. Wood chipper

S1. 2. Sitnilica drveta

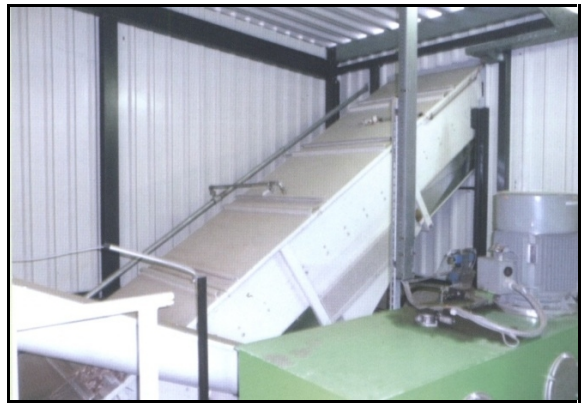

Fig 4. Dispensing conveyor of wood chips Sl. 4. Transporter dozator čipsa od drveta

Measurement of emissions, released at phytomass combustion was performed by measuring device TESTO $350 \mathrm{M} / \mathrm{XL}$, which is usually used at Department of machines and production systems. Modular system TESTO $350 \mathrm{M} / \mathrm{XL}$ consist of three main parts (Figure 5). This device is calibrated for accurate emissions measurement, while the evaluation of the measured values was based on emission limits defined by the Clean Air Act no. 137/10 and by Decree 356/2010 Coll of the Ministry of Agriculture, Environment and Regional Development of the Slovak Republic.

Gases $\mathrm{O}_{2}, \mathrm{CO}, \mathrm{CO}_{2}, \mathrm{NO}, \mathrm{NO}_{2}$, as well as control values (flue gas temperature) were selected for analysis from a variety of values, which could be measured by TESTO $350 \mathrm{M} / \mathrm{XL}$. 

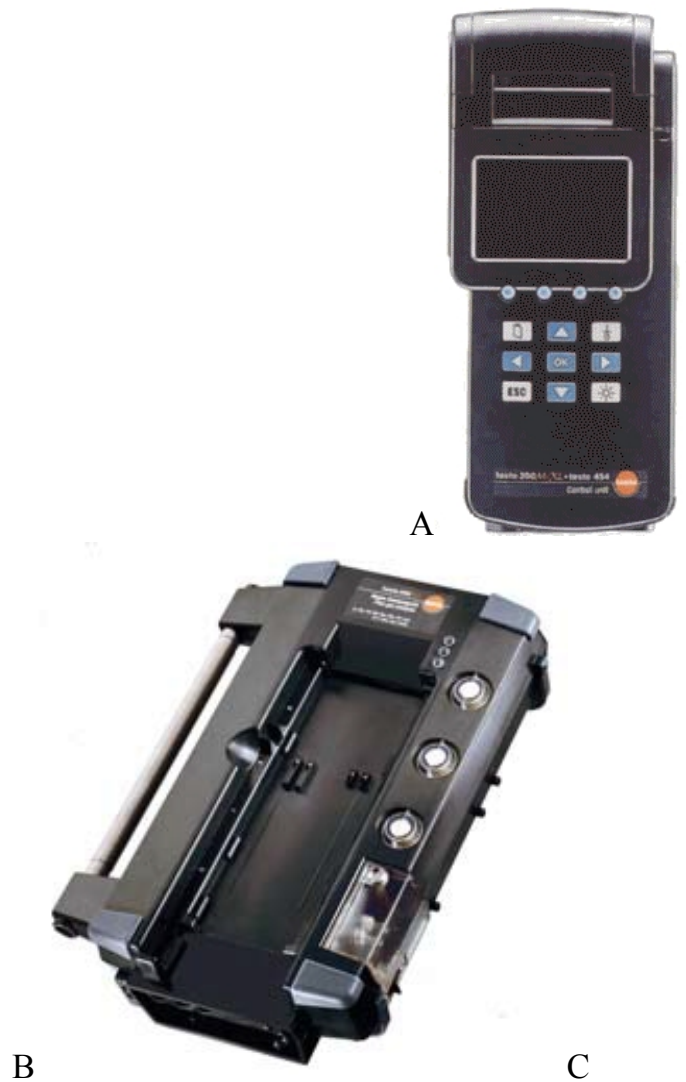

$\mathrm{C}$

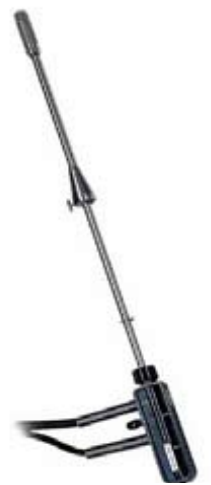

Figure 5. Modular system TESTO $350 \mathrm{M} / \mathrm{XL}$ for the analysis of flue gases: $\mathrm{A}$ - control unit, $\mathrm{B}$ - analyzer box, $\mathrm{C}$ - sampling probe

\section{RESULTS AND DISCUSSION}

We selected wood chips as a source of energy for residential buildings heating, considering opportunities of PD Rastislavice and incineration plant of Menert-Therm in Šal'a.

Comparison of parameters of measured characteristics of combustion and emissions during the combustion of wood chips

Results of experimental measurements are shown in table 2. Some values are presented in internationally recognized units of ppm (parts per million). Results of the average values of experimentally monitored emissions are statistically processed for combustion of wood chips at moisture of $20 \%$. 
Tab 2. Basic statistical parameters of the selected measured data

Tab. 2. Osnovni statistički parametri izmerenih podataka

\begin{tabular}{|l|c|c|c|c|c|}
\hline Parameter & $\mathbf{C O}, \mathbf{p p m}$ & $\mathbf{C O}_{\mathbf{2}}, \mathbf{\%}$ & $\mathbf{N O}, \mathbf{p p m}$ & $\mathbf{N O}_{\mathbf{2}}, \mathbf{p p m}$ & $\mathbf{T S},{ }^{\circ} \mathbf{C}$ \\
\hline Count & 301 & 301 & 301 & 301 & 301 \\
\hline Average & 1002,61 & 5,12 & 100,64 & 62,82 & 143,05 \\
\hline Standard deviation & 243,88 & 0,34 & 21,11 & 10,75 & 2,08 \\
\hline Coefficient of variation & $24,32 \%$ & $6,57 \%$ & $20,98 \%$ & $17,11 \%$ & $1,45 \%$ \\
\hline Minimal value & 106,0 & 3,29 & 62,0 & 8,6 & 136,9 \\
\hline Maximal value & 1591,0 & 5,74 & 145,0 & 82,5 & 145,5 \\
\hline Range & 1485,0 & 2,45 & 83,0 & 73,9 & 8,6 \\
\hline Obliquing & 0,48 & $-6,87$ & 0,11 & $-10,2$ & $-7,41$ \\
\hline Taperness & 4,02 & 16,26 & $-3,24$ & 21,82 & 0,51 \\
\hline
\end{tabular}

Measurement of $\mathrm{CO}$ content of flue gases at wood chips combustion

Measured and evaluated results are shown graphically in figure 6.

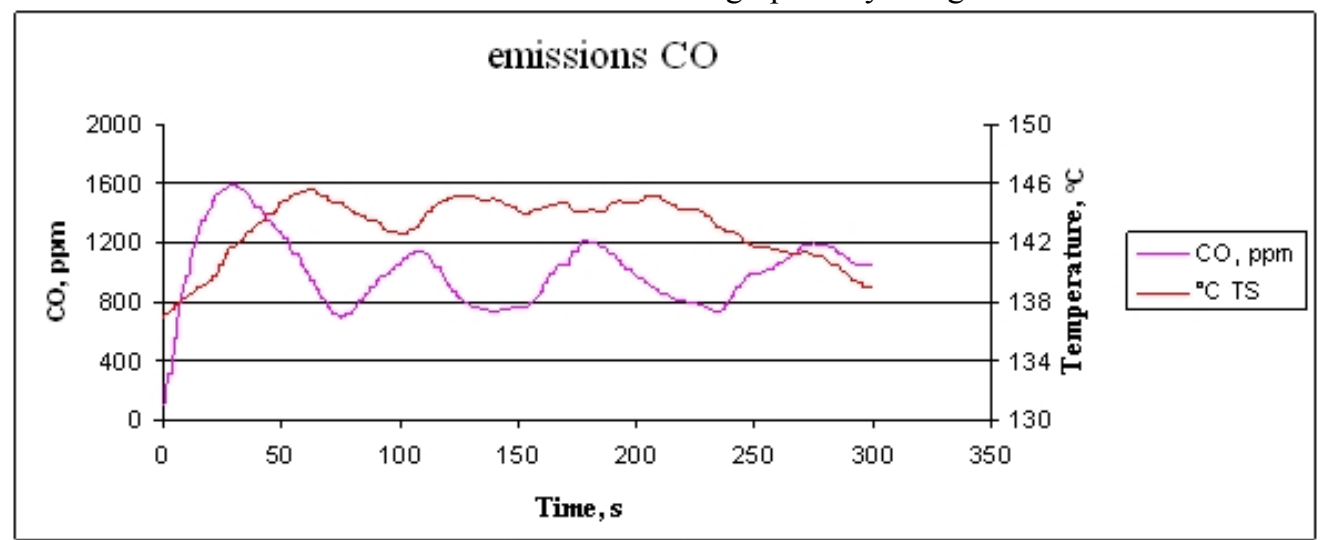

Fig. 6. The course of the gas temperature and the status of the $\mathrm{CO}$ in the flue gas during the combustion of wood chips with a moisture of $20 \%$, depending on the time of burning. S1. 6. Tok temeprature gasa i CO tokom sagorevanja čipsa od drveta vlažnosti $20 \% \mathrm{u}$ zavisnosti od vremena sagorevanja

Based on measured values, we can allege that time-scale percentage state of emissions in the flue gas has an average value of $1002,61 \mathrm{ppm}$ with a maximum value of $1591,0 \mathrm{ppm}$ and a minimum value of 106,0 ppm. As presented in graphical form, at the start of combustion (inserting of the wood chips) $\mathrm{CO}$ and flue gas temperature conditions are very different but after stabilization of combustion, monitored conditions are moving within acceptable values. 


\section{Measurement of $\mathrm{CO}_{2}$ content of flue gases at wood chips combustion}

Course of $\mathrm{CO}_{2}$ content within the timeframe is shown in figure 7. Based on measurement results, we detected very different values of $\mathrm{CO}_{2}$ emissions when inserting wood chips into the boiler and subsequent stabilization of values in the range from 3,29 to $5,74 \%$. The temperature of flue gases was in a range from 136,9 to $145,5^{\circ} \mathrm{C}$ during the measurement of monitored emission.

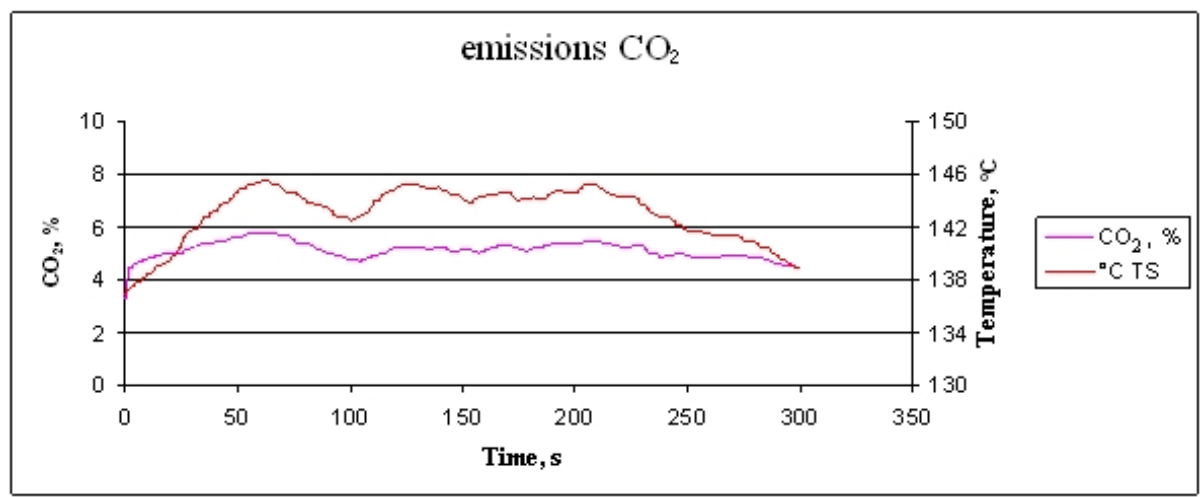

Figure 7. The course of the gas temperature and the status of the $\mathrm{CO}_{2}$ in the flue gas during the combustion of wood chips with a moisture of $20 \%$, depending on the time of burning.

\section{Measurement of NO content of flue gases at wood chips combustion}

The course of measured values of NO emissions is shown in figure 8. State of NO emission from the combustion of wood chips is very variable at the start of combustion, but after stabilization of combustion, values are within acceptable numbers around 100,6 ppm.

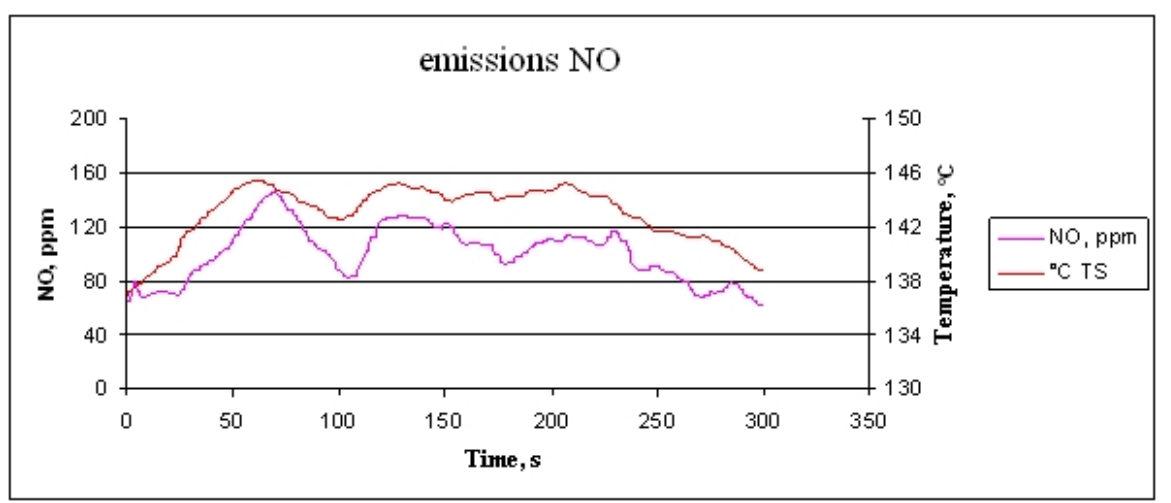

Figure 8. The course of the gas temperature and the status of the NO in the flue gas during the combustion of wood chips with a moisture $20 \%$, depending on the time of burning. 
The measurement results of $\mathrm{NO}_{2}$ emissions by modular system TESTO $350 \mathrm{M} / \mathrm{XL}$ are shown in figure 9. State of $\mathrm{NO}_{2}$ emissions from the combustion throughout the time horizon is circulating around the value of $62,02 \mathrm{ppm}$, with a minimum value of $8,6 \mathrm{ppm}$ and a maximum value of $82,5 \mathrm{ppm}$.

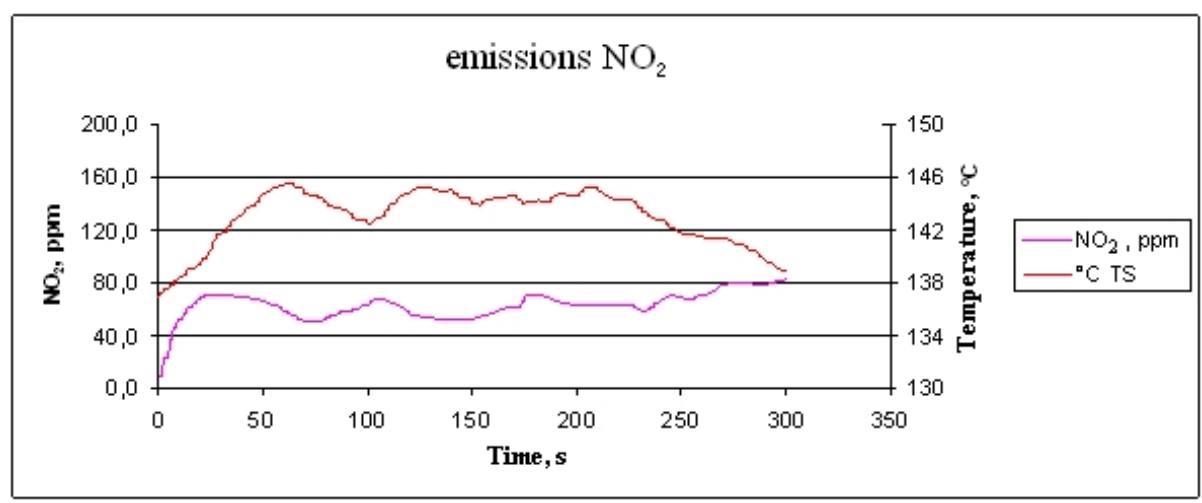

Figure 9. The course of the gas temperature and the status of the $\mathrm{NO}_{2}$ in the flue gas during the combustion of wood chips with a moisture $20 \%$, depending on the time of burning.

\section{CONCLUSIONS}

Based on measured experimental results and their assessment it can be concluded that the use of wood chips for energy purposes during combustion is real and, considering climate gas emissions, measured values are within emissions limits defined in Collection of Laws no. 356/2010, page 2955, article 1.9. Stationary equipment for combustion of fuel with a total nominal power of $0.3 \mathrm{MW}$ to $50 \mathrm{MW}$. All emissions limits are in accordance to monitored standards for $\mathrm{CO}, \mathrm{CO}_{2}, \mathrm{NO}, \mathrm{NO}_{2}$, but on the other hand it should be noted that emission values are different at the beginning than in the course of burning. The issue of dendromass harvesting considering machinery, technological and economical viewpoint within the Slovak republic is poorly understood, therefore, these issues will be the subject of further research at the Department of machines and production systems.

\section{REFERENCES}

[1] Gaduš, J. 2006. Bioplyn - efektívna alternatíva pre pol’nohospodárske podniky. In: Agrobioenergia 1/2006, s. 6-8. ISSN 1336-9660-3

[2] Maga, J., Piszczalka, J. 2006. Biomasa ako zdroj obnovitel'nej energie, Nitra: SPU, 2006, 104 s. ISBN 80-8069-679-9

[3] Piszczalka, J. - Jobbágy, J. 2011. Bioenergetika zelená energia. In: Odborná monografia. Nitra: SPU, 2011, 143 s. ISBN 978-80-552-0645-5

[4] Biomasa, 2014. Home page address: http://www.inforse.org/europe/fae/OEZ/biomasa/biomasa.html 
http://www.zbierka.sk

Elektronická zbierka zákonov, 2010. Home page address:

[6] Moderná mechanizácia v pol'nohospodárstve, 2013. Home page address: http://www.mmpress.sk/mech7/default.asp

\section{MERENJE EMISIJE GASOVA TOKOM SAGOREVANJA ČIPSA OD DRVETA}

\section{Angelovič M, Findura P, Jobbágy J, Fiantoková Soňa, Križan M}

Slovenská pol'nohospodárska univerzita v Nitre, Technická fakulta, Katedra strojov a výrobných systémov, Tr. A. Hlinku 2, Nitra, 949 76, e-pošta: marek.angelovic@uniag.sk

\section{REZIME}

Cilj ovog rada je bio praćenje dela procesa prerade drvene građe. Izvršeno je merenje energetskog potencijala drvenog čipsa tokom sagorevanja. Čips od drveta sadržao je $20 \%$ vlage. Tokom ovog eksperimenta detektovan je uticaj sadržaja vlage drvenog čipsa na emisiju $\mathrm{CO}, \mathrm{CO}_{2}, \mathrm{NO}$ i $\mathrm{NO}_{2}$. Sve izmerene vrednosti emisija bile su u skladu sa normativom definisanim direktivom 356/2010 Ministarstva poljoprivrede, životne sredine i regionalnog razvoja Republike Slovačke .

Ključne reči: drva, obnovljivi izvori energije, emisija $\mathrm{CO}, \mathrm{CO}_{2}, \mathrm{NO}$ i $\mathrm{NO}_{2}$, granične vrednosti, proces sagorevanja.

Acknowledgements:The research was created within the project Vega 1/0786/14 „The impact of the environmental aspects of the action of the techniques to eliminate degradation processes in agrotechnology of cultivation of field crops."

Primljeno: 03. 10. 2014. god.

Prihvaćeno: 16. 10. 2014. god. 